\title{
Traditional methods of processing precious metals of Sakha people
}

\author{
Varvara Dmitrieva ${ }^{1, *}$, Liliya Sidorova ${ }^{1}$, Lyudmila Amanbaeva ${ }^{1}$, Anastasiya Vinokurova ${ }^{1}$, \\ and Galina Evstafeva ${ }^{1}$ \\ ${ }^{1}$ North-Eastern Federal University, 677000 Yakutsk, Russia
}

\begin{abstract}
The article examines a little-studied topic about ancient manual technology for processing precious metals of the people of the Republic (Sakha) of Yakutia. Over the course of its long history, the basic technological operations of processing precious metals haven't lost their essence, in the process of their development they improved, modernized, but retained their unique archaism. The main content of the study is an analysis of traditional methods of processing precious metals of the Sakha people and methods of their use in modern conditions.
\end{abstract}

\section{Introduction}

The Republic of Sakha (Yakutia) occupies a fairly vast territory in Eastern Siberia of the Russian Federation. Sakha is the only ethnos that has settled in harsh climatic conditions and has retained its cultural, intellectual heritage, ethnic identity for many centuries [1]. They traditionally engaged in animal husbandry, traditionally having focused on rearing horses, fishing, hunting, and developed trade, blacksmithing and jewelry. As noted by the famous teacher, creator of ethnopedology G.N. Volkov, that the people of Sakha are the most talented of all the nomadic peoples of Siberia. This is especially evident for various types of art, including jewelry [2].

Over the course of its centuries-old history, the jewelry art of the Sakha people hasn't lost its national identity, artistic tradition, technological operations of precious metals for many centuries. Skillful jewelers were famous far beyond their native places, there were entire families involved in jewelry. They were respected people in society, had some privileges and rights [3].

\section{Materials and methods}

At the height of the first half of the 19th century, craftsmen mastered the craft well in the manufacture of not only tools, utensils, but also jewelry. In the Yakut language, masters of wood or bone, a blacksmith or a jeweler call one term "Uus".

The article reveals a little-studied topic about the identification and preservation of archaic traditions, heritage in the technology of manufacturing jewelry of Sakha people.

\footnotetext{
* Corresponding author: 1t_zhukova@mail.ru
} 
This topic is relevant in that at present, the unique, traditionally developed for centuries jewelers (Uus) of the Sakha people traditional methods of processing precious metals are forgotten. Some ancient methods of processing precious metals have survived to this day, many of them are on the verge of extinction or have completely disappeared. One of the main reasons for this problem is that blacksmiths-jewelers didn't distribute their skills, kept secret, or it was passed from father to son.

Currently, there is an active process of revival of the lost cultural values, in connection with which there is an increasing need for a more detailed study of this problem.

Researchers in their works most often turn their attention to the origin of the Sakha people and their traditional culture, historical data on the development of jewelry, types of patterning of jewelry, and modern processing technologies $[4,5,6]$.

Jewelry was perceived at all times in the inseparable unity of the aesthetic and functional in an object designed to protect, protect a person. At the same time, there is no doubt that the jewelry performed not only an aesthetic function but also carried a certain semantic load. The problems of semantics (i.e., the semantic content) of things of utilitarian and decorative purpose, and their social functions are complex and far from final solutions.

General characteristics of the jewelry art of the Sakha people. The works of Yakut jewelry art, combined with ethnographic materials, help in the reconstruction of the mythological and religious representations of the Sakha people, characterized by elements of totemistic, animistic, magical beliefs, rituals, and rites.

The best examples of the jewelry art of the Sakha people in shaping, design, and decoration are based on national traditions, the principles of simplicity and logic, rhythm and clarity of proportions, and compositional rigor. A special feature of Yakut jewelry is its monumentality, and almost sculptural expressiveness, preserved even in small forms, the rhythmic alternation of pattern and background, creating a sense of spatial symmetry in the arrangement of patterns.

The systematization of jewelry by material and technique is the basis of the structural art criticism approach to the study of jewelry works of the Sakha people. The classification of categories of jewelry by types, subtypes, and variants is based, first of all, on such features as the constituent elements of the forms (outline, design, composition, features of the geometric series: width, height, cross-section), then, where required: material, technique, ornamentation. With the deepening of the classifications covered by an increasing number of sign decorations. Due to the wide variety of forms of decoration, it is not possible to conduct a "clean" classification even within a single section.

These studies in the development of jewelry of the Sakha people are of great importance in the processing and manufacture of jewelry. However, ancient methods of processing precious metals remain poorly studied due to the lack of information in literary sources.

In this regard, we set a goal to identify ancient methods of processing precious metals of the Sakha people in the manual manufacture of jewelry. In Sakha people, the jewelry craft has been preserved most fully since ancient times, relative to other Turkic peoples, such as Altaians, Tuvans, Bashkirs, etc.

In Yakutia, they've been processing metal since ancient times. he most expressive example of the art of blacksmiths is the «ukulan»sword, found in 1943 in the village of Ukulan, Aldan district of Yakutia. In terms of manufacturing technique and shape, the sword is a masterpiece of bronze foundry. On the one hand, it resembles the steppe short sword of the Scythian period XII - VII. BC, but the general shape and crossover with the balls at the ends have no analogues in the products of steppe masters [7]

The traditional metalworking is sung in the heroic epic "Olonkho", in the oral folklore of the Sakha people. 
The method of manufacturing copper products and their decoration almost completely coincide with silver products. In this regard, it should be noted that the artistic development of copper should not be considered as the lowest, and silver - as the highest stage of development of metal processing. Ornaments and various household products made of these metals coexisted in the same period and often made up the same ensemble of ornaments in a festive outfit. Sketchy information in literature dating back to the 12th century was preserved about the skill of Yakut jewelers and their products.

The article uses scientific, historical positions, works of researchers - ethnographers of Yakutia. The traditions and bright talent of the Sakha people are evidenced by the work of prominent figures such as R.K. Maak [8], V.L. Seroshevsky [6] and others.

The first experience of studying traditional methods of manual processing of precious metals was described by F.M. Zykov [3], and no further studies were conducted on the technology of manufacturing national jewelry.

Yakut masters are characterized by manual processing of metals, which dates back to ancient times. One of the main techniques for manual processing of precious metals is the casting method.

Skilled craftsmen, very original approach to the manufacture of products using the casting method, which consists of separate operations:

The lower half of the flask was placed on a smooth wooden board and filled to the top with thick opaque clay and trimmed.

The model of the future product was half-pressed into the clay and sprayed with water

After spraying, coated with chopped charcoal

The upper and lower frames were pressed together by a clamp, while the upper frame should be filled with earth.

Dried on fire to impart greater hardness to the mold.

The model was removed, a track was applied on the hardened opaque clay to connect the fingerprint of the model.

After cooling, the molded product was taken out of the mold.

For the manufacture of larger products used openwork casting.

\section{Results and discussion}

Thus, the technical methods of processing precious metals, in particular, the traditional casting method, has a distinctive feature in the preparation of casting methods, unique tools and devices. Along with casting, the following metal processing methods were also used: forging, stamping. One of the methods of metal forming is forging. The Yakut master jeweler, in order to make forging a sheet of large silver and save material, cast an ingot plate and glowed.

The uniqueness of this method is that to cool the metal, the master jeweler immersed a heated plate in water with milk, while it becomes soft. The process of forging a hot plate consists in immersing it until a sheet of the desired thickness is obtained. Yakut masters skillfully used decorative processing of jewelry. The main ways to decorate jewelry were: engraving, chasing, blackening, gilding.

The engraving was very well developed, it was decorated with many female jewelries of the Sakha people [9]. The engraving was performed very skillfully, the ornaments made using the engraving technique looked very beautiful. With the help of engraving, both the thinnest lines of the pattern and complex ornamental compositions were created. Jewelers used it in the design of bracelets, chest plates, belt plaques and horse harness items [10].

In the literature on jewelry from other nations, similar tools, like a wooden vice for carving, tools for applying patterns are not found. 
Yakut jewelers widely used blackening to decorate silver items. The method of blackening was kept in secret by the Yakut silvermen, they differed from the melting sequence of metals, in some cases there was no use of borax. Apparently, these differences in the preparation of mobiles also influenced in obtaining various shades: bluish tint and black-brown. The first was valued higher by Sakha people.

The coincidence of the name of the substances, as well as the method of preparation and use of mobiles, indicate that the Yakut masters borrowed this method of decorating silver from Russian jewelers.

Although very limited, gilding was used, they decorated earrings, rings and crosses.

We have identified some types of ancient methods of processing precious metals that aren't reflected in these sources.

In today conditions, the use of charcoal is quite widespread. But the old technology for using charcoal is lost. When smelting a small amount of precious metal, charcoal was used instead of a melting pot.

The ancient method of using open fire soot when soldering a product in literary sources is not recorded.

Modern jewelers use the so-called flux, consisting of borax and boric acid, to protect the metal from oxidation, which with strong heating turns into a kind of glaze. Frequent fluxing promotes the formation of green plaque, which leads to significant losses of time and material [11-16].

Instead of flux, soot of open fire was used when soldering the product. The soot of fire forms an excellent protective layer against oxidation during the heat treatment of metal. When heating, for example, silver, black soot lays a thin layer on the metal. For this, burners are used: their external light cone of the torch is a source for soot. Using this technique is very convenient, efficient, and quickly ensures high quality performance.

\section{Conclusion}

As a result of studying traditional methods of processing precious metals of the Sakha people, it can be noted that basically the processing technique does not differ from the processing technology of other nations. There are differences in individual moments of the preparation of casting, in the sequence of execution, in tools and devices.

In today conditions, with the improvement, modernization of processing methods, the use of soot open flame when soldering products can be successfully used in the manual manufacture of jewelry.

\section{Reference}

1. V. V. Ushnitskiy, IIGU 14 (2015)

2. J. Forsyth, A history of the peoples of Siberia: Russia's North Asian colony 1581-1990 (Cambridge University Press, 1992)

3. F. M. Zykov Jewelry of Yakut people (Yakutsk, Kn, 1976)

4. M.E. Barakhova, JK 1 (2014)

5. A.I. Gogolev On the problem of the origin of the language of the Sakha people (Yakutsk, Akademiya nauk Respubliki Sakha, 2018)

6. V. L. Seroshevskiy, MOR 2 (1993)

7. S.V. Nikiforova, I.V. Pokatilova, The World of the Sakha: Folk Art (Yakutsk, Bichik, 2014)

8. R.K. Maak Vilyusky District of Yakutsk Oblast (Moscow, Yana,1994) 
9. I. Petrova, AEAEJ 38, 2 (2010)

10. A.I. Savvinov, M.P. Stepanova Environmental assessment and bioremediation of oilcontaminated soils in the permafrost of Yakutia (Yakutsk, Bichik, 2017)

11. L.I. Amanbaeva, U.F. Egorova, G.V. Potapov, JNP 3, 8 (2012)

12. E. Brepohl, Theorie und Praxis des Goldschmieds (Leipzig, VEB Fachbuchverlag, 1984)

13. B. Chilisa, Indigenous Research Methodologies. (London, Sage Publication Ltd, 2012)

14. E.I. Lukovtsev Sakha people jewelry (Moskow, Reglant, 2005)

15. B.F. Neustroev, Sakha oyuuta-bichige (Yakutsk: Bichik, 2010)

16. S.B. Sidel'nikov, I.L. Konstantinov, N.N. Dovzhenko, Pressing technology (Moscow, INFRA-M, 2018) 